\title{
Indicaciones para autores
}

La Revista Colombiana de Educación es una publicación del Centro de Investigaciones de la Universidad Pedagógica Nacional DGP-CIUP, orientada principalmente a la divulgación de trabajos de investigación educativa y estudios teóricos sobre el campo de la educación. A tal efecto, trabaja semestralmente con números temáticos. Se sugiere consultar la temática antes de remitir cualquier contribución.

Pautas para el envío de los artículos

1. Los trabajos no sobrepasarán las 20 páginas ó 40.000 caracteres. Dentro de la extensión está comprendido el espacio para gráficas, tablas e ilustraciones. La bibliografía no se incluye dentro de la extensión indicada.

2. El trabajo será entregado en formato carta, interlineado a espacio y medio, letra Arial, tamaño 12. Se establecerá como margen del trabajo $3 \mathrm{~cm}$ por cada lado, para encabezado $2 \mathrm{~cm}$ y pie de página 2,5.

3. Las notas de pie de página tendrán una secuencia numérica; se debe procurar que sean pocas y escuetas, deben realizarse para aclaraciones del texto más no para citar libros. Los libros consultados solo aparecerán en la bibliografía.

4. Todas las páginas deberán estar numeradas incluida la bibliografía.

5. En hoja aparte deberá incluirse el nombre del autor, título académico indicando la institución que lo otorgó, dirección postal, institución donde trabaja y cargo que desempeña, teléfono, fax y correo electrónico.

6. Cada artículo deberá llevar un resumen con mínimo 150 palabras y máximo 250 donde muestre claramente el tema, metodología y conclusión principal de su escrito.

7. Cada artículo deberá incluir 5 palabras clave con el fin de facilitar la clasificación e identificación en los diferentes índices nacionales e internacionales.

8. Las tablas deberán presentarse en formato Word o Excel (no imagen). Las ilustraciones (gráficas, dibujos, fotografías) se incluirán para aclarar la información y deben entregarse con el respectivo crédito y en formato JPG o TIF.

9. Los originales serán sometidos a un proceso editorial que se desarrollará en varias fases. En primer lugar, los artículos serán objeto de una evaluación preliminar por parte de los miembros del Comité Editorial, el Director, y el editor temático de cada edición quienes determinarán la pertinencia de su publicación.

10. Una vez establecido que el artículo cumple con los requisitos temá- 
ticos, además de los requisitos formales indicados en estas instrucciones, será enviado a dos pares académicos relacionados con cada temática, quienes determinarán, en forma anónima:

a. Publicar

b. Publicar con modificaciones

c. No publicar

11. En caso de discrepancia entre ambos resultados, el texto será enviado a un tercer árbitro cuya decisión definirá su publicación. Los resultados del proceso de evaluación serán inapelables en todos los casos. Los artículos postulados para la Revista Colombiana de Educación, deberán ser originales, inéditos, y no haber sido publicados ni enviados en ninguna de sus versiones en otra revista. La Revista Colombiana de Educación solicita a los autores de los artículos científicos, que concedan la propiedad de sus derechos de autor, para que su artículo sea publicado, editado y reproducido en cualquier forma o medio, así como su distribución en el número de ejemplares que se requieran y su divulgación en cada una de las modalidades: medios electrónicos, CD ROM, impresos o de cualquier otra tecnología para fines exclusivamente científicos, culturales, de difusión y sin fines de lucro.

12. La bibliografía debe estar escrita bajo las normas APA (American Psychological Association), sexta edición, ordenada alfabética y cronológicamente según corresponda. No usar mayúsculas continuas.

\section{Libros}

Las referencias de los libros contarán con el apellido del autor, coma, inicial del nombre o de los nombres seguida de un punto, año entre paréntesis, punto, título del libro (en letra cursiva y solo con mayúscula la primera letra; excepciones: la primera letra después de dos puntos de un título en inglés, nombre de instrumentos, congresos o seminarios y nombres propios), punto, ciudad, dos puntos, editorial y punto. Para el caso de libro completo con una edición diferente, se pone la edición entre paréntesis después del título, dejando un espacio y en letra normal (se abrevia ed.)

\section{Artículo en revista}

Las referencias de los artículos de revistas científicas se inicia con el apellido, coma, inicial del nombre, punto, nombre del artículo en letra normal, coma, se incluye la palabra "en" para indicar el nombre de la revista, nombre de la revista en cursiva, coma, volumen y edición, coma, páginas del artículo separadas por guión y punto.

\section{Fuentes electrónicas}

Los documentos publicados en Internet que se citen como referencia irán después de la bibliografía bajo el título "Fuentes electrónicas". Contarán con el autor, nombre, coma, inicial, punto, año de publicación entre paréntesis, punto, título del documento, punto, título de la revista (si es el caso) en cursiva, y se complementarán con la fecha de consulta y la dirección electrónica (URL) en donde está disponible. 
Se debe proveer información para identificar y localizar el documento consultado con las siguientes palabras "Recuperado en" o una frase equivalente y la palabra "de" para indicar la dirección electrónica (URL).

\section{Ejemplos}

\section{Libros:}

Albano, S. (2006). Michel Foucault, glosario epistemológico. Buenos Aires: Quadrata.

Baudrillard, J. (1991). La transparencia del mal. Ensayo sobre los fenómenos extremos. Barcelona: Anagrama.

Revistas:

Martínez, A. (2010). Prejuicio moral e instrucción: dos obstáculos para la incorporación de los pardos a la Nación, en Revista Colombiana de Educación, número 59, pp. 14-32.

Fuentes electrónicas:

Lugo, L. (2007). Educación virtual y hegemonía cultural. Una mirada desde la interculturalidad. En: Revista Electrónica Razón y Palabra, recuperado en septiembre de 2009, de www.razonypalabra.org. $\mathrm{mx} /$ anteriores/n61/varia/lugo.html

\section{Objetivo de la Revista}

La Revista Colombiana de Educación es editada por el Centro de Investigaciones de la Universidad Pedagógica Nacional, Colombia, con una periodicidad semestral (se publica en julio y diciembre). Publicación de referencia para los estudiosos de la educación y pedagogía. La Revista se dirige a especialistas en temáticas educativas y pedagógicas, al magisterio en general y a estudiantes universitarios de pregrado y posgrado de las áreas de Educación, Ciencias Sociales y Humanidades.

Revista Colombiana de Educación

Centro de Investigaciones DGP-CIUP-

Universidad Pedagógica Nacional

Calle 127 \# 11-20

Bogotá - Colombia

rce@pedagogica.edu.co / rceupn@gmail.com

(057-1) 6156537 - 6261048

Página web:

http://www.pedagogica.edu.co/revistas/ojs/index.php/RCE 
(fecha)

\section{Señores}

\section{Comité Editorial}

\section{Revista Colombiana de Educación}

Centro de Investigaciones - Universidad Pedagógica Nacional

Pormedio delapresente certifico miautoría del trabajotitulado

que estoy presentando para la posible publicación en la Revista Colombiana de Educación, producida y editada por el Centro de Investigaciones de la Universidad Pedagógica Nacional, y declaro que el artículo no ha sido publicado ni presentado en otra publicación científica seriada.

El artículo es original de mi autoría e inédito.

Asimismo, declaro que todos los materiales incluidos están identificados con su respectivo crédito e insertados en las citas y la bibliografía.

En el caso de la aprobación del artículo, autorizo su publicación, reproducción, edición, distribución y divulgación a nivel nacional e internacional por medios impresos, digitales, Internet, CD ROM, en texto completo o parcial.

Como contraprestación estoy de acuerdo en recibir dos (2) ejemplares de la edición en donde aparece el artículo de mi autoría.

Como constancia de lo anterior, se firma a los días del mes de del año en la ciudad de

\section{Agradezco la atención prestada}

Atentamente

Nombre (primer autor)

Firma

Afiliación institucional

CC

Programa académico

Dirección de correspondencia

Teléfono

Correo electrónico 


\section{Instructions for Authors}

Revista Colombiana de Educación (The Colombian Journal of Education) is a publication by Universidad Pedagógica Nacional's Research Center DGP-CIUP, primarily engaged to disseminate educational research papers and theoretical studies on education. For this purpose, topic issues are released biyearly. Be sure to consult the issue before submitting any contribution.

Guidelines for Submitting Articles

1. Articles may not exceed 20 pages or 40,000 characters, including space for graphics, tables and illustrations. Bibliographic references are not included within the total indicated.

2. Articles will be delivered in letter format, 1.5 spaced, font Arial, size 12. Set margins as follows: $3 \mathrm{~cm}$ each side, header $2 \mathrm{~cm}$, and footer 2.5 .

3. Footnotes have a number sequence; just few and brief as possible; only for text clarification text but not books cited. Books only in bibliographic references.

4. All pages should be numbered, including bibliographic references.

5. A separate sheet should include the author's name; academic degrees, indicating institution(s); mailing address; institution affiliation and job title; phone, fax and email.

6. Each paper should have an abstract of 150-250 words showing clearly the topic, a methodology, and a main conclusion of the writing.

7. Each article should include 5 keywords to ease sorting and identification for different national and international indexes.

8. Tables/charts should be submitted with Word or Excel format (no pictures included). Illustrations (graphs, drawings, photographs) are included to explain the information and should incorporate the relevant reference in JPG or TIF.

9. Manuscripts have a phased edition process. First, articles should be given a preliminary assessment by the Editorial Board, the Director, and the Editor of each issue, who determine the relevance of the publication.

10. Once topic requirements met besides the formalities specified in this guide, the article will be sent to 2 anonymous academic peers specialized in each topic, who will determine one of these:

a. Publish

b. Publish including changes

c. Do not publish

11. Article then will be sent to a third arbitrator whose decision will 
define the publication if discrepancy between them. The results of the evaluation process will be final in any case.

Articles submitted should be original, unpublished, or have not been printed or submitted simultaneously by other journals.

Upon Revista Colombiana de Educación's request, author(s) should attach a copyright authorization, so that article may be published, edited and reproduced in any form, as well as distribution in the number of copies and disclosure required for each form, i.e. electronic, CD ROM, printed or any other technology form, but nonprofit and just strictly scientific, cultural and dissemination purposes.

Below an authorization letter sample which must be attached with the article.

12. Bibliographic References should follow American Psychological Association Guidelines, Sixth Edition, alphabetical and chronological accordingly. Do not use upper-case.

\section{Books}

Reference of books should be as follows: author's surname, comma, first name(s) followed by a period, year in brackets, period, book title -italics and capitalize only the first letter; exceptions: first letter for an English title after a colon; name of documents, conferences or seminars and proper names-, period, city, colon, publisher, and full stop. In case of a book with a different edition, it is written in brackets after the title, leaving a space with normal font (ed. abbreviated.)

\section{Journal Articles}

A reference of scientific journal articles begins with author's last name, comma, first initial, period, article's name using normal font, comma; then includes word "in" (en) to indicate Journal's name in italics, comma, volume and edition, comma; article pages separated by a hyphen, and full stop.

\section{Electronic Sources}

Documents published on Internet and cited as a reference should be after $\mathrm{Bi}$ bliographic References under "Electronic Sources," including author's surname, name, comma, initial, period, publication year in brackets, period, document title, period, Journal title (if any) in italics, and supplementing with consultation date and electronic address (URL) where available.

Information should be provided to identify and locate document cited with words "Retrieved from" (Recuperado en) or an equivalent phrase with word "from" (de) to indicate the electronic address (URL).

\section{Examples}

\section{Books:}

Albano, S. (2006). Michel Foucault, glosario epistemológico. Buenos Aires: Quadrata. 
Baudrillard, J. (1991). La transparencia del mal. Ensayo sobre los fenómenos extremos. Barcelona: Anagrama.

\section{Journals:}

Martínez, A. (2010). Prejuicio moral e instrucción: dos obstáculos para la incorporación de los pardos a la Nación, en Revista Colombiana de Educación, número 59, pp. 14-32.

\section{Electronic Sources:}

Lugo, L. (2007). Educación virtual y hegemonía cultural. Una mirada desde la interculturalidad. En: Revista Electrónica Razón y Palabra, recuperado en septiembre de 2009, de www.razonypalabra.org. $\mathrm{mx} /$ anteriores/n61/varia/lugo.html

\section{Journal Objective}

Revista Colombiana de Educación is a six monthly publication (July and December) by Universidad Pedagógica Nacional's Research Center, Colombia. This Journal is a reference for education and pedagogy scholars. Targeted to specialists in educational and pedagogical issues, teaching in general, and undergraduate and postgraduate students of Education, Social Sciences and Humanities.

Revista Colombiana de Educación

Centro de Investigaciones DGP-CIUP-

Universidad Pedagógica Nacional

Calle 127 \#11-20

Bogotá - Colombia

rce@pedagogica.edu.co / rceupn@gmail.com

(057-1) 6156537 to 6261048

Website:

http://www.pedagogica.edu.co/revistas/ojs/index.php/RCE 


\section{Editorial Board}

\section{Revista Colombiana de Educación}

Centro de Investigaciones - Universidad Pedagógica Nacional

\section{Dear Sirs}

I hereby certify my authorship of article entitled which I am submitting for a possible publication in Revista Colombiana de Educación, produced and edited by Universidad Pedagógica Nacional's Research Center, and I declare this article has not been published or submitted for any other series scientific publication.

The article is originally written by me and unpublished. Also I state that every material here is identified with its relevant credits and incorporated into the citations and bibliographic references. Whether article approved, I authorize its publication, reproduction, editing, distribution and dissemination at national and international levels by fully or partially printing, digital, Internet, or CD ROM formats.

In return I agree to receive two (2) copies of the issue where my article is published. As evidence hereinbefore, signed on (day), (month), (year) in (city).

Thank you

\section{Very truly yours}

Name (first author)

Signature

Institution Affiliation

CC

Academic Program

Mailing Address

Phone

Email 